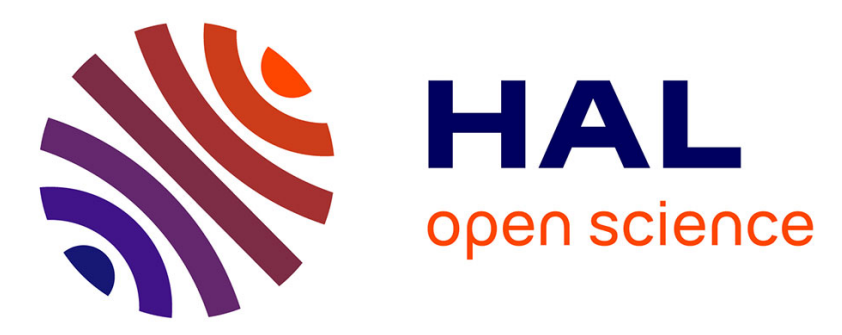

\title{
A portable biosensor system for bacterial concentration measurements in cow's raw milk
}

\author{
Marco Grossi, Massimo Lanzoni, Anna Pompei, Roberto Lazzarini, Diego \\ Matteuzzi, Bruno Ricco
}

\section{To cite this version:}

Marco Grossi, Massimo Lanzoni, Anna Pompei, Roberto Lazzarini, Diego Matteuzzi, et al.. A portable biosensor system for bacterial concentration measurements in cow's raw milk. Proceedings of the 4th IEEE International Workshop on Advances in Sensors and Interfaces (IWASI), 2011, Jun 2011, Savelletri di Fasano, Italy. hal-01276551

\section{HAL Id: hal-01276551 \\ https://hal.science/hal-01276551}

Submitted on 25 Feb 2016

HAL is a multi-disciplinary open access archive for the deposit and dissemination of scientific research documents, whether they are published or not. The documents may come from teaching and research institutions in France or abroad, or from public or private research centers.
L'archive ouverte pluridisciplinaire HAL, est destinée au dépôt et à la diffusion de documents scientifiques de niveau recherche, publiés ou non, émanant des établissements d'enseignement et de recherche français ou étrangers, des laboratoires publics ou privés. 


\title{
A portable biosensor system for bacterial concentration measurements in cow's raw milk
}

Marco Grossi $^{\mathrm{a}^{*}}$, Massimo Lanzoni ${ }^{\mathrm{a}}$, Anna Pompei ${ }^{\mathrm{b}}$, Roberto Lazzarini ${ }^{\mathrm{c}}$, Diego Matteuzzi ${ }^{\mathrm{b}}$, Bruno Riccò $^{\mathrm{a}}$

${ }^{a}$ Department of Electronic Engineering (D.E.I.S.), University of Bologna, Bologna, Italy

${ }^{\mathrm{b}}$ Department of Pharmaceutical Sciences, University of Bologna, Bologna, Italy

${ }^{\mathrm{c}}$ Carpigiani Group, Anzola Emilia, Bologna, Italy

* Corresponding author Tel.: +39 0512093082; Fax: +39 0512093785; e-mail address: marco.grossi8@unibo.it

\begin{abstract}
Bacterial detection is of primary importance in many fields, such as food and environmental monitoring. Measurements of bacterial concentration are traditionally carried out by means of the Standard Plate Count technique, a reliable method for microbial screening that, however, features long response time and is carried out by qualified personnel in microbiology laboratories. The impedance technique for bacterial concentration detection represents a method very competitive with Standard Plate Count in terms of response time (3-12 hours vs. 24-72 hours) as well as for the possibility to be realized in automatic form.

This paper presents an embedded portable biosensor system for the measurement of bacterial concentration in cow's raw milk. The possibility to perform measurements "on the field", hence without the need to ship samples to distant laboratories, and to transmit the data on wireless communication systems or on the Internet represents a substantial advantage in terms of time and cost, thus making the presented system an important tool for in-situ bacterial screening.
\end{abstract}


Keywords: portable biosensor, embedded system, wireless communication, impedance, microbial detection, raw milk bacteria.

\section{Introduction}

Microbial detection is essential in important applications, such as, for instance, quality control in the food industry and environmental control. In particular, in the USA, food pathogens are responsible for an estimated 14 million illnesses, 60000 hospitalizations and 1800 deaths every year [1]. National and international laws exist that impose a maximum microbial concentration for different types of samples as well as the absence of dangerous pathogens in order to guarantee consumer health. This holds also for the screening of bacterial concentration in environmental waters and, in particular, for drinking water that undergoes different treatments (such as filtering and chlorination) to assure the absence of pathogens.

The measurement of bacterial concentration is usually carried out by means of the Standard Plate Count technique (SPC) [2], deriving the bacterial concentration from the number of colony forming units (cfu) grown on Petri plates filled with enriching media containing agar and inoculated with serial dilution of the sample. The technique is reliable but also time consuming (24-72 hours depending on the type of sample) and needs to be performed by skilled staff in microbiology laboratories. With the SPC, samples of the product to be tested are shipped to the labs for analysis producing results a few days later. Since contaminations can occur during different steps of the production process, an automatic tool for screening the product along the entire production line would greatly improve the quality control.

A variety of biosensors for the food industry are available that are highly competitive with SPC in terms of speed, with response time ranging from 20 minutes to few hours. Such biosensors are based on different transduction techniques, such as optics [3], bioluminescence [4], piezoelectricity [5], amperometry [6], flow cytometry [7]. Although very efficient in terms of response time, all these methods require rather complex procedures making them substantially unsuitable for use 
outside the laboratories. On the contrary, the sensing technique based on impedance microbiology [8] is very attractive since it is competitive with SPC in terms of response time (3-12 hours depending on the bacterial contamination vs. 24-72 hours), can be carried out by unskilled personnel and even implemented in automatic form.

The impedance technique, detecting the change in the sample electrical parameters induced by bacterial metabolism [9][10], works essentially as follows [11]. The sample under test is stored at a temperature favouring bacterial growth within a chamber featuring measurement electrodes, and the electrical characteristics of the system electrodes-electrolyte are measured at regular time intervals by stimulating the sample with a sinusoidal test signal. From an electrical standpoint, at frequencies $<1 \mathrm{MHz}$, the electrodes-electrolyte system can be described as the series of a resistance $\mathrm{R}_{\mathrm{s}}$ (accounting for the resistance of both the sample and the electrode-electrolyte interface) and a capacitance $\mathrm{C}_{\mathrm{s}}$ (related to the formation of a double layer region at the electrode- electrolyte interface) [12]. Until the bacterial concentration is lower than a critical threshold (in the order of $10^{7}$ cfu/ml), after a initial stabilization, both $\mathrm{R}_{\mathrm{s}}$ and $\mathrm{C}_{\mathrm{s}}$ remain essentially constant (at their baseline values). When, however, the bacterial concentration grows above the critical threshold, $\mathrm{R}_{\mathrm{S}}$ begins to decrease while $\mathrm{C}_{\mathrm{s}}$ increases. The time needed for the electrical parameters to deviate from the baseline values, hereafter denoted as Detect Time (DT), presents a linear relationship with the logarithm of the sample bacterial concentration: hence, this latter can be easily worked out from the measured value of DT. The impedance technique has been used to measure bacterial concentration in different type of samples, such as ice-cream [13][14], water [15] and beer.

The impedance technique has been used in different commercial instruments for the detection of microbial concentration, such as Bactometer by Vitek Systems Ltd (Basingstoke, UK), Malthus by Malthus Instruments Ltd (Bury, UK), Bac Trac by Sy-Lab (Purkensdorf, Austria) and RABIT by Don Whitley Scientific (Shipley, UK). All these systems share the same principles and differ essentially for the electrodes material (stainless steel or platinum) and the frequency of the applied test signal. 
We, instead, have developed an original embedded portable system [16] that detects bacterial concentration in liquid and semi-liquid media based on the impedance technique. Our system is highly competitive with the commercial products based on the same (impedance) technique since it is portable, hence suitable for in-situ measurements and quality control along the entire production process, while the alternative solutions are essentially benchtop instruments to be used in laboratory environment. Moreover, the use of cheap electronics makes our system highly competitive in terms of cost (few hundreds USD). Recently, we have also developed a web based application to share the biosensor results with different users in the world.

The biosensor system described in this work has been used to measure the bacterial concentration in raw milk samples, representing a very challenging case because raw milk contains a large diversity of different type of bacteria, each featuring a different optimal grow temperature. In experiment to validate the system, two different incubation temperatures have been tested as well as the possibility to add enriching media to the sample in order to improve the noise-to-signal ratio and reduce the response time.

\section{The biosensor system}

The biosensor of this work is composed of three parts. A thermoregulation board, based on the $\mu$ controller ATmega168 by Atmel (California, USA), regulates the sample temperature by means of an ad hoc algorithm exploiting the proportional-integral-derivative (PID) technique, that allows the sample temperature to be stabilized with oscillations lower than $0.15^{\circ} \mathrm{C}$. For reliable measurements it is important that the incubation temperature be maintained as stable as possible since the measured electrical parameters $\left(R_{s}\right.$ and $\left.C_{s}\right)$ are strong function of temperature. The oscillations of sample temperature produce variations in the measured electrical parameters [16] affecting the accuracy and reliability of DT estimation. The second board, based on the $\mu$-controller ARM STR912 by STMicroelectronics, is devoted to the measurement of the sample electrical parameters and the extraction of the DT. The use of a state-of-the-art 16 bit ADC converters, as well as suitable 
hardware and software filtering guarantee electrical parameter estimation with an accuracy higher than $99.9 \%$. The incubation chamber features a volume capacity of $4 \mathrm{ml}$. A couple of stainless steel electrodes, placed in direct contact with the sample, allows to measure the relevant electrical parameters $\left(\left|Z_{s}\right|, R_{s}\right.$ and $\left.C_{s}\right)$. Furthermore, two temperature sensors (LM135 by National Semiconductor and PT100) are integrated in the chamber for temperature sensing, while heating is produced by means of a couple of adhesive power resistances $(24 \Omega, 15 \mathrm{~W}$ maximum power, $24 \mathrm{~V}$ $50 \mathrm{~Hz}$ power supply). The incubation chamber has been realized with the following procedures: a copper foil, used to transmit heat to the sample, is applied with the adhesive power resistances, a cylindrical support is drilled to allow inserting the stainless steel electrodes, heat diffuser and temperature sensors. The whole chamber parts are then sealed with a bi-components thermosetting resin, characterized by low thermal conductivity minimizing the influence of environmental temperature variations. An Atom based eeePC (communicating with the boards via serial RS232 interface) is integrated in the system for on-line graphical representation of the measured data, setting the assay parameters and data filing. All the programs are written with LabVIEW by National Instruments (Texas, USA). The maximum power consumption of the system (excluding the eeePC) is $10 \mathrm{~W}$, a relatively low value compatible also with battery supply.

The sample electrical parameters are determined by applying to the electrodes a sinusoidal test signal $\mathrm{V}_{\text {in }}(\mathrm{t})\left(100 \mathrm{mV}_{\mathrm{PP}}, 200 \mathrm{~Hz}\right)$ and measuring the current drawn $\mathrm{I}_{\text {in }}(\mathrm{t})$ by means of a current to voltage $(I / V)$ converter with output $V_{\text {out }}(t)=-\left(R_{F} / Z_{s}\right) \cdot I_{i n}(t)$, where $R_{F}$ is the converter feedback resistor. The electrical parameters $\mathrm{R}_{\mathrm{s}}$ and $\mathrm{C}_{\mathrm{s}}$, calculated using the $\mathrm{R}-\mathrm{C}$ series model as discussed in [13], can be expressed as $R_{s}=\left(V_{\text {Min }} / V_{\text {Mout }}\right) R_{F} \cos (\varphi)$ and $C_{s}=\left(1 / 2 \pi f R_{F}\right)\left(V_{M o u t} / V_{M i n}\right)(1 / \operatorname{sen}(\varphi))$, where $\mathrm{V}_{\text {Min }}, \mathrm{V}_{\text {Mout }}$ and $\varphi$ are the amplitudes for the signals $\mathrm{V}_{\text {in }}(\mathrm{t})$ and $\mathrm{V}_{\text {out }}(\mathrm{t})$ and the phase difference respectively.

A more detailed description for the biosensor's hardware is provided in [16], while a picture of the system and a schematic of the interconnections within the biosensor parts are shown in Fig. 1 (a) and in Fig. 1 (b) respectively. 
The system of this work features remote communication. In particular, wireless data transfer is made possible by a GT 863-PY terminal by Telit (Italy) and an Ethernet port for worldwide communications. This allows rapid collection of the data even at large distances, easy data sharing among different users, and the creation of networks of biosensors deployed at the milk collection points for real-time, distributed quality control. At this regard, a web application has been developed to store results from different equipments. It has been programmed using the generalpurpose scripting language PHP with HTML and Cascading Style Sheets (CSS) for web pages presentation. AmCharts library by amCharts (Vilnius, Lithuania) has been used to realize graphic data representation. This library allows to realize graphics in Flash and is capable to extract data from Microsoft Excel files XML or read dynamically generated data with PHP, Java, Ruby on Rails, Pearl, ColdFusion and many other programming language [17] .

When entering the web application with his id and password, the user is presented with a list of all the biosensors accessible with his privilege (for each biosensor it is specified the institution/place where it is positioned as well as the last time it was accessed). Once a biosensor has been chosen, the list of all measurements made with that system can be seen. Each measurement is described with the type of sample analyzed, the date and time the assay was performed. Thus, the user can see the data of a single assay (curves representing $R_{s}$ and $C_{s}$ vs time, the sample temperature, the bacterial concentration determined by SPC and eventual notes about the assay). In addition, he can also compare data from different samples obtained with the same biosensor or for the same sample measured with different biosensors, for comparison and control. A schematic of the web application organization is shown in Fig. 2.

A system of passwords and user privileges has been implemented in order to create a hierarchical structure where high level users have access to their own data as well as to those of lower level users. Four levels have been implemented: the highest one is reserved to the Administrator, who has access to all data as well as having the possibility to control the biosensors in order to modify the assay settings. In descending order, the Technicians level allows access to data of the associated 
biosensor equipments, while that dedicated to Customers allows to see only data obtained with their own assays. Finally, the lowest level only allows access to limited information on some assays.

\section{Results and discussion}

The portable biosensor described in this work has been used to measure bacterial concentrations in cow's raw milk. The samples have been provided by different milk farms near Bologna (Italy).

The correct incubation temperature is a critical point for the application of the impedance technique, since different bacterial strains are characterized by different mean generation times $\left(T_{G}\right)$, i.e. mean time between cell duplication, strongly dependent on temperature. Since the bacterial concentration is inferred by the time needed for the bacterial population to reach the critical threshold of $10^{7}$ $\mathrm{cfu} / \mathrm{ml}$, in order to obtain a good correlation between DT and microbial concentration it is necessary to choose the incubation temperature so as to minimize the dispersion in $\mathrm{T}_{\mathrm{G}}$ for all the bacterial strains potentially present in the sample.

At this regard, raw milk presents a large number of potentially present microorganisms characterized by different values of $\mathrm{T}_{\mathrm{G}}$. In particular, raw milk bacteria can be divided in two relevant groups: psychrotrophic and mesophilic strains. Psychrotrophic bacteria include species with the shortest $\mathrm{T}_{\mathrm{G}}$ (i.e. faster growth rate) at temperatures in the range $7-15^{\circ} \mathrm{C}$. For mesophilic strains, on the other hand, the optimal growth conditions (i.e. minimum $\mathrm{T}_{\mathrm{G}}$ ) are in the temperature range $30-37^{\circ} \mathrm{C}$.

Common raw milk contaminants include (but are not limited to) Pseudomonas, Aeromonas, Streptococcus, Lactobacillus as well as coliform and enterococci strains. Data from the literature are very controversial about the best choice of incubation temperature: some of the pioneering works on impedance microbiology [18] reported good correlation between DT and bacterial concentration from SPC at $18^{\circ} \mathrm{C}$ (i.e at a temperature representing a trade-off between the optimal temperature for mesophilic and psycrotrophic strains), while bad results were obtained at $30^{\circ} \mathrm{C}$ (best condition for mesophilic strains growth and standard temperature for SPC). However, more recent 
papers reported slightly better results at $30^{\circ} \mathrm{C}$ [19] in terms of correlation with SPC. In this work, assays have been carried out at both $18^{\circ} \mathrm{C}$ and $30^{\circ} \mathrm{C}$.

As for results, the curves $C_{s}$ vs. $t$ present a more regular behaviour than that $R_{s} v s t$, with more stable baseline values, thus leading to more reliable determination of DT. Therefore, $\mathrm{C}_{\mathrm{s}} \mathrm{vs}$. $\mathrm{t}$ curves have been used to obtain the results discussed below.

Fig. 3 shows the percent increase of $\mathrm{C}_{\mathrm{s}}$ for a couple of samples characterized by different values of bacterial concentration and for both incubation temperatures of $30^{\circ} \mathrm{C}$ and $18^{\circ} \mathrm{C}$. As can be seen, higher contaminated samples feature lower values of DT than samples with lower microbial concentration, while incubation at $18^{\circ} \mathrm{C}$ produced slower biosensor response (higher values of DT) for the same bacterial concentration than at $30^{\circ} \mathrm{C}$.

Fig. 4 shows scatter plots for the assays carried out at both $18^{\circ} \mathrm{C}$ and $30^{\circ} \mathrm{C}$. The graphs report the measured values of DT vs total bacterial concentration (logarithmic scale) measured by SPC in Lauria Bertani (LB) agar. Linear regression line and the determination factor $\mathrm{R}^{2}$ are shown as well. The figure shows a good linear relation between DT and logarithm of microbial concentration for both incubating temperatures. However the dispersion, mainly due to differences in $\mathrm{T}_{\mathrm{G}}$ among different bacteria strains, is smaller in the case of $18^{\circ} \mathrm{C}\left(\mathrm{R}^{2}{ }_{18^{\circ} \mathrm{C}}=0.728>\mathrm{R}^{2}{ }_{30^{\circ} \mathrm{C}}=0.485\right)$. The values of $T_{G}$ for both cases can be inferred by the linear regression equation $D T=A \cdot \log \left(C_{0}\right)+B$, as also shown in [14] and the results are $\mathrm{T}_{\mathrm{G} 18^{\circ} \mathrm{C}}=247.4$ minutes, $\mathrm{T}_{\mathrm{G} 30^{\circ} \mathrm{C}}=47.5$ minutes. The mean generation time at $18{ }^{\circ} \mathrm{C}$ is five times higher than that at $30^{\circ} \mathrm{C}$, thus resulting in much slower biosensor response. A trade-off between measurement accuracy and response time is thus mandatory.

To improve the correlation with SPC and decrease response times, the possibility to dilute the sample in enriching media has been investigated. Three different media have been selected, based on their property to favour bacteria growth in raw milk, namely: yeast extract diluted in water in concentration 3\% (YE3\%); casaminoacids; LB, modified to eliminate the presence of high salt content. Casaminoacids addition resulted in irregular curves, irreproducible behaviour and high 
noise-to-signal ratio (probably due to the high conductivity of the media interfering with the electrical changes due to bacterial metabolism). YE3\% and LB, on the other hand, produced good results: the obtained curves are generally more regular, with more stable baselines, leading to reliable determination of DT. No significant difference between sample diluted in YE3\% and LB has been detected: thus in subsequent experiments LB has been used as enriching media, since it is effective on a larger number of milk bacteria.

The effect of dilution of different concentration of LB in raw milk samples has been investigated. Fig. 5 shows curves for the same sample diluted in different concentration of LB, for the incubation temperature of $30^{\circ} \mathrm{C}$. As can be seen, increasing the LB concentration leads to more regular curves with steeper variations when the critical bacteria concentration is reached, thus leading to more reliable determination of DT. Moreover, higher LB concentration results in a richer medium for bacterial replication thus producing higher microbial growth rate and faster biosensor responses.

\section{Conclusions}

This paper has presented an embedded portable biosensor system for bacterial concentration detection that is consistent with Standard Plate Count (SPC) technique while exhibiting significant advantages in terms of response time (3-12 hours vs. 24-72 hours) and of the possibility of in-situ measurements without shipping samples to microbiology laboratories. The developed biosensor is suitable for data transfer with both Internet and wireless communication systems, and a web application for sharing data with a hierarchical level of user privileges has been developed, that can be used for quality control in industrial environments.

The biosensor has been tested measuring bacterial concentrations in cow's raw milk samples. The results show a good linear relation between biosensor response and bacterial concentrations measured by SPC, with non negligible dispersions mainly due to difference in growth rate between the different bacteria present in the samples. 
The sample incubation temperature of $18^{\circ} \mathrm{C}$ results in higher correlation with $\mathrm{SPC}$ than $30^{\circ} \mathrm{C}$, but is also characterized by significantly slower response. The addition of Lauria Bertani medium to the tested samples results in more regular curves with benefits to the measurement reliability and faster response time.

\section{Acknowledgments}

This work has been financially supported by Spinner 2013 program, funded by Regional Operational program 2007-2013 (Emilia Romagna, Italy), Ministry of Labour, Health and Social Policy (Italy) and the European Social Fund (ESF).

\section{References}

1. Mead, P.,Slutsker, L., Dietz, V., "Food-related illness and death in the united states", Emerging Infectious Diseases, Vol. 5, No. 5 (1999), pp. 607-625.

2. Kaspar, C. W., Tartera, C., Methods in Microbiology, R. Grigorova \& J.R. Norris eds. (London: Academic Press, 1990), pp. 497-531.

3. Swenson, F. J., "Development and evaluation of optical sensors for the detection of bacteria”, Sensors and Actuators B : Chemical, Vol. 11 (1993), pp. 315-321.

4. Stanley, P. E., “A review of bioluminescent ATP techniques in rapid microbiology”, Journal of Bioluminescence and Chemiluminescence, Vol. 4, No. 1 (2005), pp. 375-380.

5. Plomer, M., Guilbault, G.G., Hock, B., "Development of a piezoelectric immunosensor for the detection of enterobacteria”, Enzyme and Microbiology Technology, Vol. 14 (1992), pp. 230235.

6. Perez, F., Tryland, I., Mascini, M., Fiksdal, L., "Rapid detection of escherichia coli in water by a culture-based amperometric method", Analitica Chimica Acta, Vol. 427 (2001), pp. 149-154. 
7. Gunasekera T.S., Attfield P.V., Veal D.A., “A Flow Cytometry Method for Rapid Detection and Enumeration of Total Bacteria in Milk", Applied and Environmental Microbiology, Vol. 66, No. 3 (2000), pp. 1228-1232.

8. Firstemberg-Eden, R., Eden, G., Impedance Microbiology (Wiley: New York, 1984), pp. 154-196.

9. Lanzanova, M., Mucchetti, G., Neviani, E., “Analysis of conductance changes as a growth index of lactic acid bacteria in milk", Journal of Dairy Science, Vol. 76, No. 1 (1993), pp. 20-28.

10. Neviani, E., Veneroni, A., Bossi, M.G., "Utilizzazione della tecnica conduttimetrica per lo studio della crescita e dell'attività metabolica in latte di ceppi appartenenti alla specie streptococcus thermophilus", L'industria del Latte, Vol. 26, No. 2 (1990), pp. 3-21.

11. Silley, P., Forsythe, S., "Impedance microbiology - a rapid change for microbiologists", Journal of Applied Bacteriology, Vol. 80 (1996), pp. 233-243.

12. Sengupta, S., Battigelli, D.A., Chang, H.C., "A micro-scale multi-frequency reactance measurement technique to detect bacterial growth at low bio-particle concentrations", Lab on $a$ Chip, Vol. 6 (2006), pp. 1-11.

13. Grossi, M., Lanzoni, M., Pompei, A., Lazzarini, R., Matteuzzi, D., Riccò, B., "Detection of microbial concentration in ice-cream using the impedance technique", Biosensors and Bioelectronics, Vol. 23 (2008), pp. 1616-1623.

14. Grossi, M., Pompei, A., Lanzoni, M., Lazzarini, R., Matteuzzi, D., Riccò, B., “Total bacterial count in soft-frozen dairy products by impedance biosensor system", IEEE Sensors Journal, Vol. 9, No. 10 (2009), pp. 1270-1276.

15. Grossi, M., Pompei, A., Lanzoni, M., Lazzarini, R., Riccò, B., Matteuzzi, D., "Detection of coliforms concentration in water samples by portable impedance-based biosensor system", Ecomondo (Rimini, Italy, 2010), pp. 1062-1067. 
16. Grossi, M., Lanzoni, M., Pompei, A., Lazzarini, R., Matteuzzi, D., Riccò, B., “An embedded portable biosensor system for bacterial concentration detection", Biosensors and Bioelectronics, Vol. 26 (2010), pp. 983-990.

17. <www.amcharts.com>

18. Firstemberg-Eden, R., Tricarico, M.K., "Impedimetric determination of total, mesophilic and psychrotrophic counts in raw milk", Journal of Food Science, Vol. 48 (1983), pp. 1750-1754.

19. Piton, C., Dasen, A., "Evaluation de le mesure d'impédance comme technique rapide d'appréciation de la qualité bactériologique du lait cru”, Le Lait, Vol. 68, No. 4 (1988), pp. 467-484. 
Figure 1: Picture of the biosensor system (a) and interconnections between the different system components (b).

Figure 2: Schematic for page access in the web application for the biosensor system.

Figure 3: Percent increase of $\mathrm{C}_{\mathrm{s}}$ in the case of two samples featuring different microbial contamination $\left(3 \cdot 10^{4} \mathrm{cfu} / \mathrm{ml}\right.$ and $\left.10^{7} \mathrm{cfu} / \mathrm{ml}\right)$ for the incubation temperatures of $30^{\circ} \mathrm{C}$ and $18^{\circ} \mathrm{C}$.

Figure 4: Scatter plots representing the measured Detect Time as function of the bacterial concentration determined by Standard Plate Count for the incubation temperatures of $30^{\circ} \mathrm{C}$ and $18^{\circ} \mathrm{C}$.

Figure 5: Percent increase of $C_{s}$ for a sample with a bacterial concentration of $2 \cdot 10^{4} \mathrm{cfu} / \mathrm{ml}$ diluted in different ratios with the enriching media LB. 

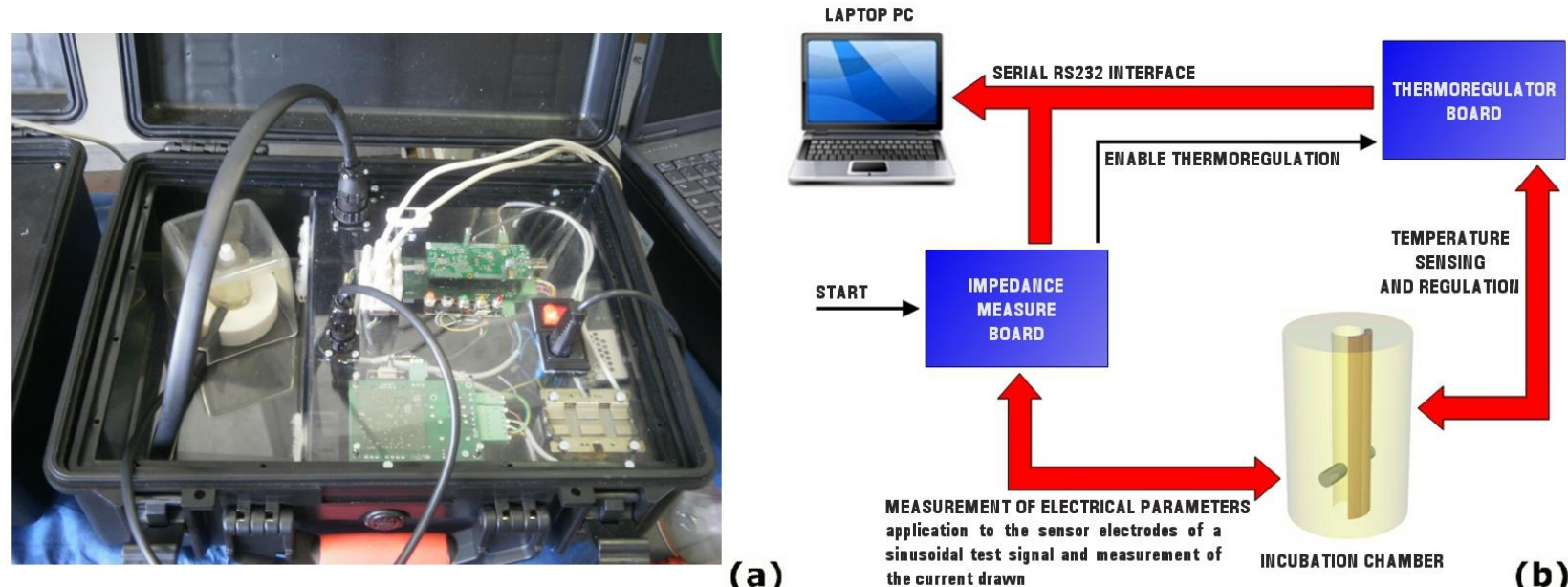

Fig. 1 


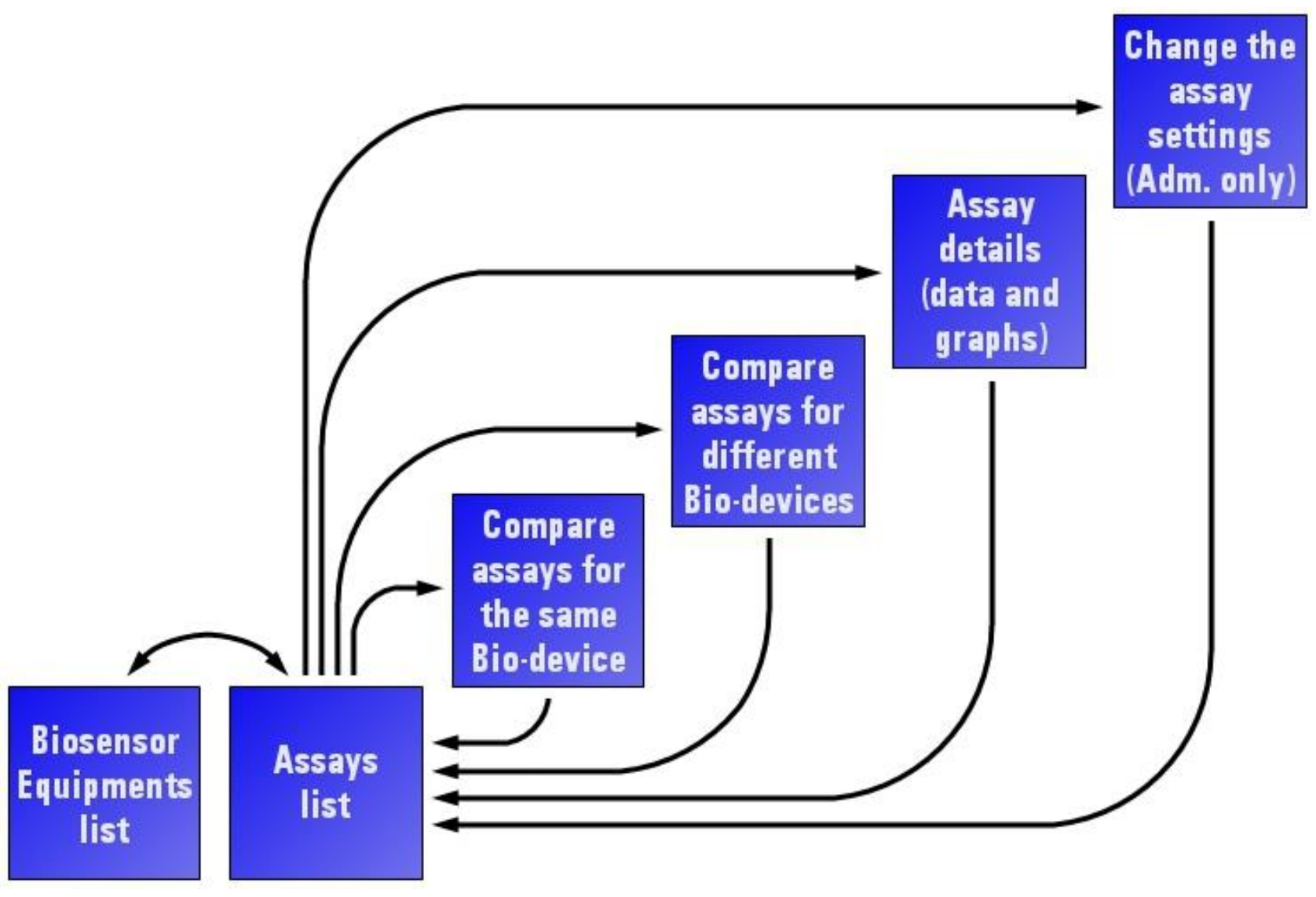

Fig. 2 

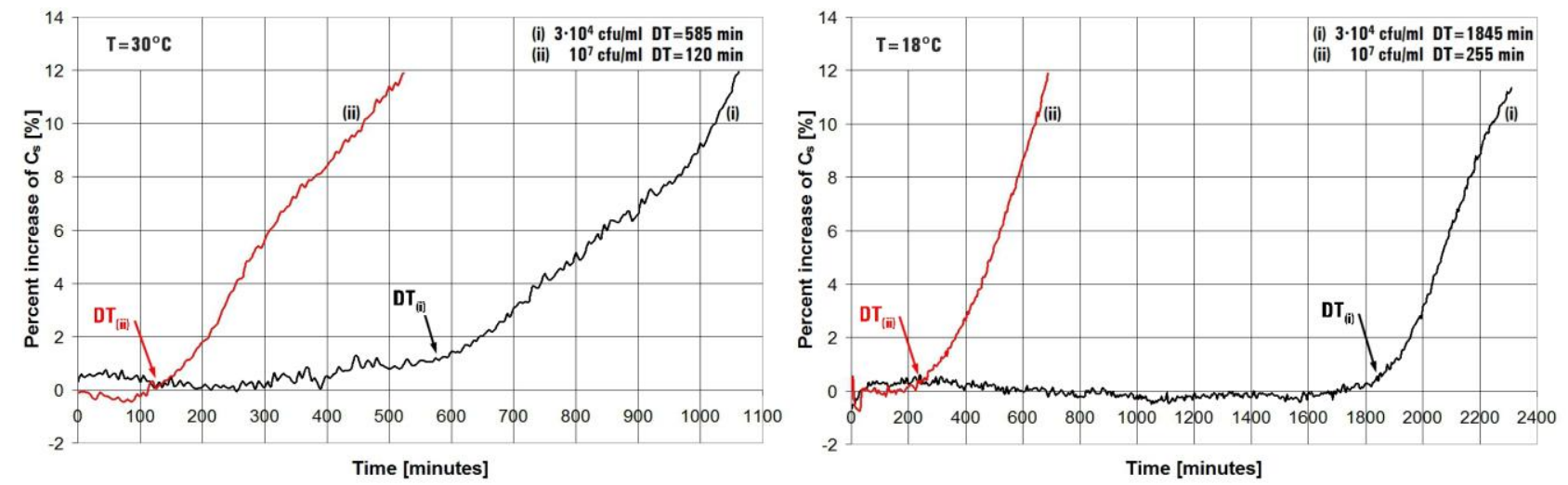

Fig. 3 

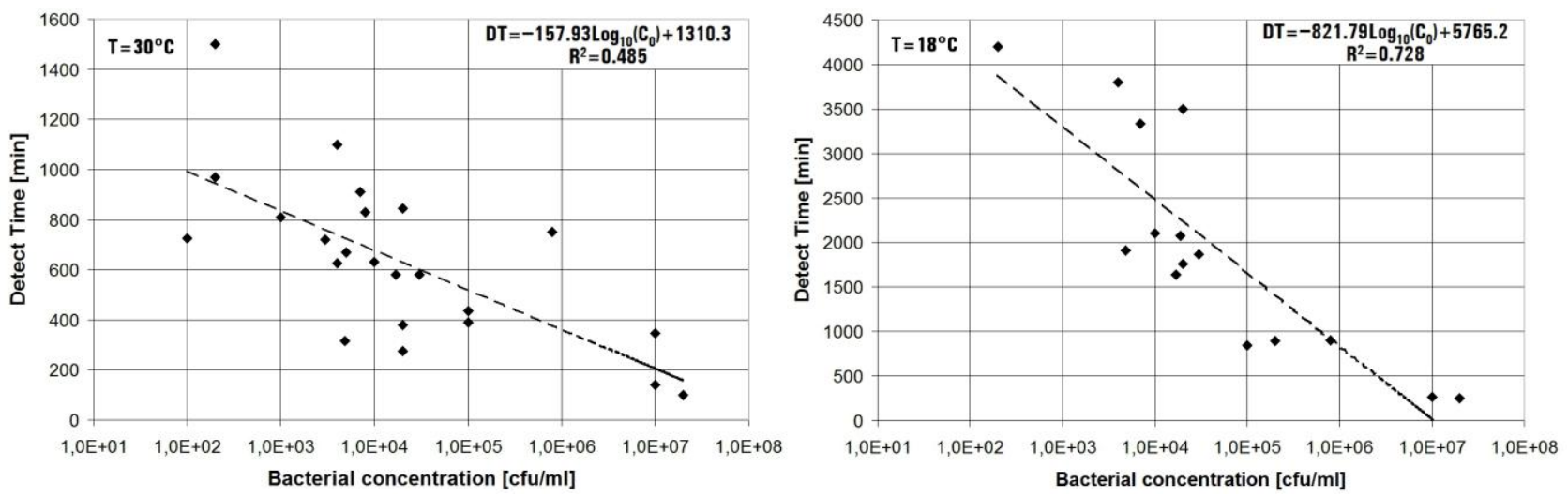

Fig. 4 


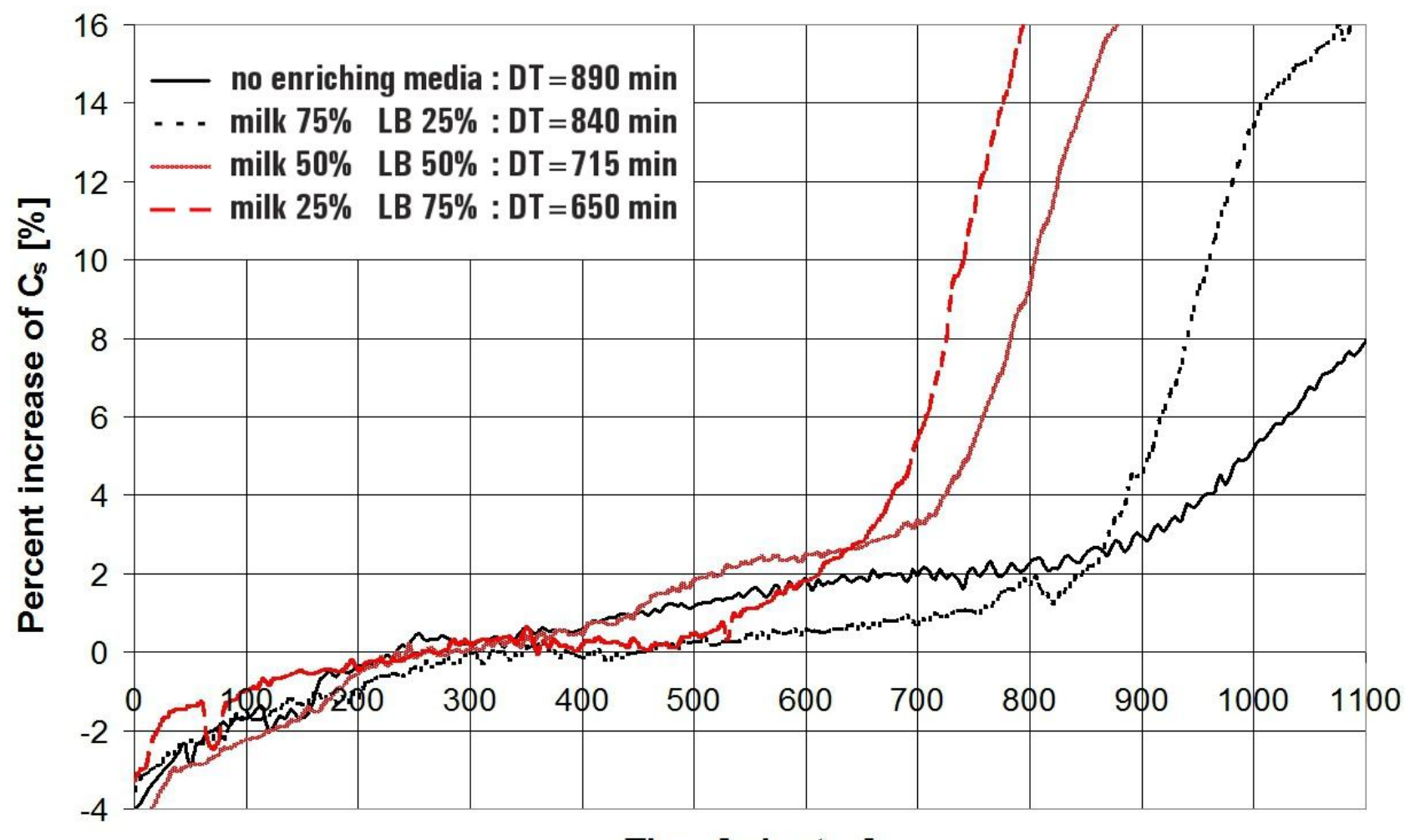

Time [minutes]

Fig. 5 